\title{
The Influence of Service Quality on Public Satisfaction and Public Trust: A Study on Jakarta Public Health Services during COVID-19 Pandemic
}

\author{
Baiq Sany Ayu Citra ${ }^{a}$, Bambang Setiono ${ }^{b}$, Christian Haposan Pangaribuan ${ }^{c}$, \\ Maria Francisca Lies Ambarwati ${ }^{\text {d }}$ \\ a, b, c Sampoerna University, Jakarta, Indonesia \\ ${ }^{\mathrm{d}}$ STIKS Tarakanita, Jakarta Indonesia
}

\begin{abstract}
Objective - The COVID-19 pandemic has challenged the government because of the uncertainty in public health services' preparedness to provide patient-centered care that meets public needs. Hence, the necessity to evaluate service quality towards society's satisfaction and trust during these difficult times. This study examines the influence of service quality towards public satisfaction and public trust on the public health services in Jakarta during the pandemic.

Methodology - A quantitative method using regression data analysis with a total sample of 120 respondents.

Findings - The result shows that two dimensions of public service quality (empathy and reliability) significantly influenced public satisfaction. However, the other three dimensions of public service quality (tangible, responsiveness, and assurance) did not influence public satisfaction. Only two dimensions of public service quality (reliability and responsiveness) significantly influenced public trust. The result found that public satisfaction positively influenced public trust. The relation was strongest compared to other correlations in the study.

Novelty - This study examined public health services by the government of Jakarta during the COVID-19 pandemic. Keywords: COVID-19 Pandemic; Public Health Service; Public Service Quality; Public Satisfaction; Public Trust
\end{abstract}

JEL Classification: D80, G22, Z12

Article info: Received 7 March 2021; Revised 8 April 2021; Accepted 17 May 2021

Article Correspondence: christian.pangaribuan@sampoernauniversity.ac.id

Recommended Citation: Citra, B. S. A., Setiono, B., Pangaribuan, C. H. P., \& Ambarwati, M. F. L. (2021). The Influence of Service Quality on Public Satisfaction and Public Trust: A Study on Jakarta Public Health Services during COVID-19 Pandemic. Journal of Business, Management, and Social Studies, 1(1), 48-57.

\section{INTRODUCTION}

In early 2020, World Health Organization (WHO) declared COVID-19 as a pandemic disease that has spread widely to multiple countries around the world (World Health Organization, 2020). The total number of deaths of COVID-19 per 23 March 2020 was 14,602 deaths with 338,307 cases (European Centre for Disease Prevention and Control, 2020). Italy was the highest total confirmed number of deaths globally, with 5,476 total deaths and 59,138 cases, followed by China, where the first COVID-19 pandemic originated, with 3,276 deaths and 81,649 cases. As the largest country in Southeast Asia, Indonesia recorded a significant number of cases, with 48 deaths from 514 cases per 23 March 2020.

As soon as the COVID-19 outbreak began spreading across the world, thousands of people started facing critical health issues, and death rates escalated. Pandemic is always challenging because of the uncertainty (Pandey, 2020). Moreover, the pandemic is testing the preparedness of public health services in providing safe patient-centered care and meeting the population's needs (Garg et al., 2020). Providing public health services has become one of the essential obligations of any government under this pandemic situation. On the other hand, severe public health problems have created physical and psychological stress and trauma to registered nurses unprepared to deal with (Kim et al., 2018). The condition will accordingly 
have some effects on the quality of health services given to the public. Yusuf (2017) suggested that customers' perception of service quality is positively associated with government trust. Christensen and Laegreid (2005) found a connection between people's satisfaction with public services and their trust in government. The citizens who are satisfied with the services offered by the public health service, employment, and social services have a higher level of trust in public institutions than those who are not satisfied with the services (Gille et al., 2014). Delivering quality health service in dealing with COVID-19 will determine overall public satisfaction to the governments. Public satisfaction on COVID-19 health services delivery will determine public trust in governments (Christensen \& Laegreid, 2005).

This study aims to examine the influence of service quality using Parasuraman et al.'s (1988) SERVQUAL dimension and Baskoro et al.'s (2016) measurements on public satisfaction and public trust in the public health services in Jakarta during COVID-19 pandemic. This study investigates public satisfaction to the government in providing COVID-19 health services and assesses its impact on public trust in the government. Back in 2017, OECD reported that Indonesia ranked first in public trust in government (Putri et al., 2020). This study will find whether the Indonesian government can still command high public trust under the COVID-19 pandemic with the respect that several studies have documented growing dissatisfaction and distrust in government (Davenport et al., 2020).

Adapting past studies' models, this study investigates the correlation between service quality, public satisfaction, and public trust in the government (Baskoro et al., 2016; Song et al., 2019; Chang et al., 2013). We extend their study on private services to government services in Indonesia, examining the five dimensions of service quality: tangible, responsiveness, reliability, assurance, and empathy. We also investigate the influence of public satisfaction on public trust in the government. This study limits the analysis to Jakarta government public health services since it was the first epicenter of COVID-19 in Indonesia.

\section{LITERATURE REVIEW}

\section{Service Quality}

Forbes et al. (2006) define government performance as the character and consequences of public agencies. Boyne (2002) also identified government performance as the number of outputs, quality of outputs, efficiency, equity, outcomes, value for money, and consumer satisfaction. Government performances in the public health sector can be seen in its performance to deal with the COVID-19 pandemic. Indonesia confirmed 14,032 cases, 2,698 recovered, and 973 deaths. The first case of infection In Indonesia was reported on 2 March by the national government, but Jakarta's provincial government has begun monitoring and tracking potential coronavirus cases in January (Massola, 2020). The Jakarta governor had prepared for the risks before the national government decided to deal with the spread of COVID-19. The governor has met with all hospitals in Jakarta and established a hotline number for 190 hospitals in Jakarta to phone in suspect cases. It suggests the national government has a different strategy from the Jakarta government to deal with the spread of COVID-19 in Indonesia.

Quality of service is the difference between customer's expectations towards the services encounter and their perception of the service received (Karunarathne et al., 2015). Berry et al. (1988) argued that service quality is an organization's ability to fulfill customer expectations (Parasuraman et al., 1998). When the customer experience below expectations means the customer will judge the quality of service is low. While if the customer meets its expectation, the customer will value the quality of services as high as expected. Gronroos (1984) also mentions that perceived quality in given services is defined as the outcome of an evaluation process, where the customer compares its expectations with the perceived services. As an example, the customer puts perceived service against the expected service (Gronroos, 1984).

Service quality is the key to successful organizations, either private or public organizations. Service quality is critical within the service industries since it builds up a competitive advantage to achieve customer 
satisfaction within the market (Baskoro et al., 2016). Many companies focus on differentiating their competitive advantages to distinguish their services' quality (Boshoff \& Gray, 2004). When the service quality increases, customer satisfaction increases (Van de Walle \& Bouckaert, 2003).

Berry et al. (1988) have introduced the method in measuring the service quality, known as SERVQUAL, a method to represent service quality as the discrepancy between a customers' expectations and perception towards service offering. SERVQUAL model includes five dimensions, which are tangible, reliability, responsiveness, assurance, and empathy. The method of SERVQUAL in measuring the service quality has applicability in various industries such as hospitals, local government, retailing, restaurant, banking, telecommunication, airline, hotels, and education. Yusuf (2016) used different service quality measures to evaluate the performance of a government unit in Kendari City. His measure of service quality was accountability, responsiveness, orientation to services, and efficiency.

\section{Public Satisfaction}

Public satisfaction would be an essential aspect of measuring government performances. By definition, satisfaction means a positive feeling felt by the customer after receiving a service or product (Salehi et al., 2018). Chang et al. (2013) defined public satisfaction as consumer satisfaction with the services, consumer right decision to choose the services, and recommending the services to other consumers. According to Van de Walle and Bouckaert (2003), satisfaction depends on whether one has sympathy for what the agency does (mission) and whether one thinks it is suitable for society.

The increased quality of services leads to increased satisfaction among citizens (Kampen et al., 2003). Moreover, Yusuf (2017) found that public satisfaction shows a direct and significant effect on public trust. They were confirmed by Christensen and Laegreid (2005), who found a connection between people's satisfaction with public services and government trust. It means that the citizen who is satisfied with the services offered by the public health service has a higher level of trust in public institutions than the citizen who is not satisfied with the services. Therefore, public satisfaction with the quality of public health services is essential to be analyzed. By knowing the public's level of satisfaction, the government will help improve their quality of services and trust towards public health services.

\section{Public Trust}

Trust is essential because it enables the government to act without force for every decision made (Kampen et al., 2003). It means that the government will perform confidently in providing the service to the public. Trust, by definition, means dealing with interpersonal trust (Bouckaert \& Van de Walle, 2003). Trust is the customer's belief towards the people's product or services (Di Virgilio \& Antonelli, 2017). Hence, public trust will be achieved when the government's performance meets the expectations of the public. Song and Park (2019) measure public trust as meeting the promises given, believing in public services, and meeting public service expectations.

Kruk and Laugesen (2012) found that customers' perception of service quality is positively associated with government trust. Their research also reported that customers with a higher quality of services were more likely to trust the government than the customer who experienced lower quality of service. Rubogora (2017) found that the quality of service directly affects customer trust significantly, which means the better the service quality provided, the higher the customer's trust. Yusuf (2017) found service quality affects public satisfaction, but it does not affect public trust in a government unit in Kendari City in Indonesia.

This study uses service quality measures in the private sector and used different methods used by Yusuf (2017) to investigate the correlation between service qualities, public satisfaction, and public trust. We test this relation under a life-threatening situation where government services are much needed to survive every individual in Indonesia. 


\section{Service quality and public satisfaction}

Since the first cases of COVID-19 in March 2020, the reported numbers have increased rapidly, with more than 1.2 million cases in Indonesia; therefore, Public health services play essential roles in facing the outbreak COVID-19 pandemic (World Health Organization, 2020). The point is not only giving services but also how the public feels about the service given. In this case, the public's satisfaction towards health service measures the differences between the expectations of the service provider's performance and the evaluation of the service they received (Gronroos, 1984). This statement implies that public satisfaction can be achieved if they get what they expect, and it depends significantly on the service quality of the public service provided. Al-Damen (2017), in his research applied in the health care industry, showed that service quality influenced the patient's satisfaction (Al-Damen, 2017). Hence, this study proposes that:

\section{Hypothesis 1 (H1): Service quality influences public satisfaction.}

\section{Service quality and public trust}

Dealing with the pandemic, the Indonesian government must be deeply involved in handling many infected cases (Adly et al., 2020). This means that the government must show its preparedness and seriousness in dealing with COVID-19 cases. A study done by Firmansyah et al. (2020) revealed that public health management's preparedness in facing the COVID-19 pandemic would improve the service quality of the public health service (Firmansyah et al., 2020). The preparedness of the public health service is not only in providing the facilities such as hospitals, medical equipment, medicines, and the people who work in the health industry but also in how the public health service management runs the institution's operation. Mosadeghrad (2011) defined health service quality as having effective and efficient health services according to the latest clinical guidelines and standards. In summary, the studies above revealed that service quality implied the practice of good governance. A study by Azhar and Azzahra (2020) showed that good governance improved public trust. Hence, this study proposes that:

\section{Hypothesis 2 (H2): Service quality influences public trust.}

\section{Public satisfaction and public trust}

In the Organization at a Glance 2017, Indonesia got the first rank for public trust in the government based on data released by the Organization for Economic Co-operation and Development (OECD) (H. Purwanto, 2017). The overall condition in 2017 was very different from the condition of the country in 2020. People panicked and felt frightened by the pandemic spread, and this condition affects the people's trust in the government (Nicomedes \& Avila, 2020). The link between performance and trust can only be created when there are very specific conditions. It is evident that the public service's performance has a particular impact on government trust (Van de Walle \& Bouckaert, 2003). Hence, this study proposes a hypothesis that.

Hypothesis 3 (H3): Public satisfaction influences public trust. 


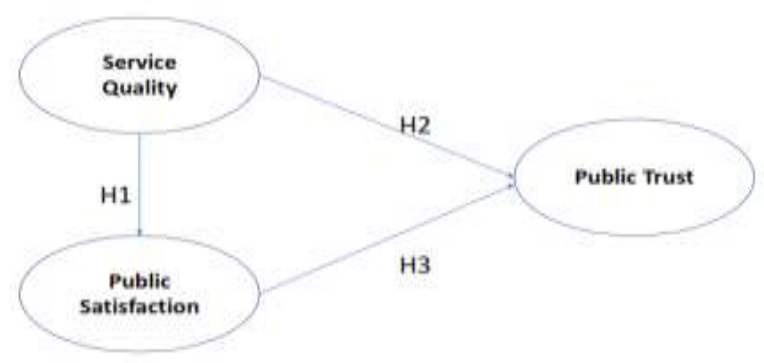

Figure 1. Framework Model

\section{METHODOLOGY}

The sampling method used in this study was the purposive sampling method. The determination of the number of samples in this study was based on Hair et al.'s (2013) argument that to get representative samples from a population, the number of indicators had to be multiplied by $5-10$. The questionnaires were adapted from the questionnaires which were designed by Baskoro et al. (2016), Song et al. (2019), and Chang et al. (2013). The data were collected from $20^{\text {th }}$ to $28^{\text {th }}$ of May 2020. The total sample of this study was 120 respondents. Data collection was done by distributing questionnaires through an online survey platform to Jakarta citizens who had already used the public health services to deal with COVID-19. The questionnaires were distributed through social media and messaging applications such as Line, WhatsApp, Twitter, and Instagram. The design of the questionnaire in this study used the Likert scale where the researcher asked the agreement of the respondents in six options, ranging from 1 (strongly disagree), 2 (disagree), 3 (somewhat disagree), 4 (somewhat agree), 5 (agree), and 6 (strongly agree). Chomeya (2010) suggests a 6-point Likert scale is more reliable than a 5-point Likert scale. The framework model for this study is shown in Figure 1.

In this study, three multiple regression models were used to test the hypothesis based on the framework.

$$
\mathrm{Y}_{\mathrm{PS}}=\beta_{0}+\beta_{1} \mathrm{X}_{1}+\beta_{2} \mathrm{X}_{2}+\beta_{3} \mathrm{X}_{3}+\beta_{4} \mathrm{X}_{4}+\beta_{5} \mathrm{X}_{5}+\mathrm{e} \quad \text { (Model 1) }
$$

Where $Y_{P S}$ is Public Satisfaction with government services (PS), $X_{1}$ is Tangible (TA), $X_{2}$ is Reliability (RE), $X_{3}$ is Responsiveness (RS), $X_{4}$ is Assurance (AS), $X_{5}$ is Empathy (EM). $\beta_{0}$ is the intercept; $\beta_{1}, \beta_{2}, \beta_{3}$, $\beta_{4}, \beta_{5}$ coefficients of the related independent variable, $e$ is the error term.

$$
\mathrm{Y}_{\mathrm{PT}}=\beta_{0}+\beta_{1} \mathrm{X}_{1}+\beta_{2} \mathrm{X}_{2}+\beta_{3} \mathrm{X}_{3}+\beta_{4} \mathrm{X}_{4}+\beta_{5} \mathrm{X}_{5}+\mathrm{e}
$$

(Model 2)

Where $\mathrm{Y}_{\mathrm{PT}}$ is Public Trust (PT), and all independent variables are presented in Model 1.

$$
\mathrm{Y}_{\mathrm{PT}}=\beta_{0}+\beta_{1} \mathrm{X}_{1}+\mathrm{e}
$$

Where $Y_{\mathrm{PT}}$ is Public Trust (PT), $\mathrm{X}_{1}$ is Public Satisfaction (PS), $\beta_{0}$ is the intercept, $\beta_{1}$ is the Coefficient of Variable, e is the error term.

We hypothesis that all independent variables were positively correlated to dependent variables for all models described above. 


\section{RESULTS AND DISCUSSION}

The researcher measured each of the five dimensions of service quality: tangible, reliability, responsiveness, assurance, and empathy. From 130 responses questionnaires distributed, only 120 responses were valid for the study. Among 120 respondents, 54.2 percent of respondent were male. The majority of the respondent was aged between 18-22 years (58.3 percent) with an education level of S1 (51.7 percent), and university student (48.3 percent). The validity and reliability test results of all independent variables suggested that all independent variables were valid with the Kaiser Meyer-Olkin (KMO) value and AntiImage Correlation higher than 0.5. All independent variables were also reliable, with Cronbach's Alpha higher than 0.7. Table 1 below presents the mean values of all variables used in this study. The lowest service quality was reliability, with a mean value of 4.45 , followed by tangible (4.57) and public satisfaction (4.58). Consumers of COVID-19 services had more trust (4.64) in the Jakarta government than satisfaction (4.58) of the services. The highest value of service quality was empathy, with a mean value of 4.84 .

Table 1. Descriptive Statistics

\begin{tabular}{cc}
\hline Variable & Final Mean Value \\
\hline Tangible & 4.57 \\
Reliability & 4.45 \\
Responsiveness & 4.59 \\
Assurance & 4.76 \\
Empathy & 4.84 \\
Public Satisfaction & 4.58 \\
Public Trust & 4.64 \\
\hline
\end{tabular}

Table 2 presents the results of the multicollinearity test of all independent variables. The tolerance value of all variables was more than 0.1, and their Variance Inflation Factor (VIF) values were less than 10. The test results suggested no multicollinearity in the regression models.

Table 2. Multicolinearity

\begin{tabular}{llcc}
\hline \multirow{2}{*}{ Model } & \multicolumn{2}{c}{ Collinearity Statistics } \\
\cline { 2 - 3 } & Tangible & Tolerance & VIF \\
\hline \multirow{4}{*}{$1 \& 2$} & 0.335 & 2.986 \\
& Reliability & 0.298 & 3.358 \\
& Responsiveness & 0.317 & 3.154 \\
& Assurance & 0.325 & 3.078 \\
& Empathy & 0.304 & 3.285 \\
\hline \multicolumn{2}{c}{ Dependent Variable: Public Satisfaction (Model 1) or Public Trust (Model 2) }
\end{tabular}

Table 3 presents the results of regressions of the three models used in this study. Results for Model 1 gave us reliability, assurance, and empathy variables as factors that influence public satisfaction on the government services to deal with COVID-19, at least at a 90 percent confidence level. Reliability and empathy variables showed a higher significant confidence level of 95\%. The reliability and assurance variables were adapted from Baskoro et al. (2016). Furthermore, this study adapted Chang et al. (2013) for measuring public satisfaction. Reliability variable measured the quality of the government's information, protection of consumer privacy information, and public image from getting the health services. Assurance variable measures security of using public health services, manners of public health workers when they provide the services, and public health workers' ability to provide the correct information. The empathy variable was adapted from Song and Park (2019). The empathy variable measured public health workers' ability to meet the public expectation on service delivery, public health workers' ability to understand the 
unique needs of consumers, and the diligence of public health workers when delivering the services. Consistent with the descriptive statistic discussed earlier, empathy gave the highest impact on public satisfaction with a beta coefficient of 0.391 . These were public health performances valued by consumers of public health service in Jakarta during COVID-19. These performances led to public satisfaction with the COVID-19 services provided in the Jakarta area.

Table 3. Multiple Linear Regression Results

\begin{tabular}{|c|c|c|c|c|c|c|}
\hline & \multirow[t]{2}{*}{ Model } & \multicolumn{2}{|c|}{$\begin{array}{c}\text { Unstandardized } \\
\text { Coefficients }\end{array}$} & \multirow{2}{*}{$\begin{array}{c}\begin{array}{c}\text { Standardized } \\
\text { Coefficients }\end{array} \\
\text { Beta } \\
\end{array}$} & \multirow[t]{2}{*}{$\mathbf{t}$} & \multirow[t]{2}{*}{ Sig. } \\
\hline & & B & Std. Error & & & \\
\hline \multirow{6}{*}{$\begin{array}{l}1 \text { Dependent } \\
\text { Variable } \\
\text { (DV): } \\
\text { Public } \\
\text { Satisfaction }\end{array}$} & Constant & 1.134 & 1.056 & & 1.074 & 0.285 \\
\hline & Tangible & 0.136 & 0.108 & 0.130 & 1.253 & 0.213 \\
\hline & Reliability & $0.232 * *$ & 0.102 & 0.250 & 2.269 & 0.025 \\
\hline & Responsiveness & 0.013 & 0.103 & 0.013 & 0.124 & 0.902 \\
\hline & Assurance & $0.198 *$ & 0.109 & 0.192 & 1.822 & 0.071 \\
\hline & Empathy & $0.319 * *$ & 0.126 & 0.275 & 2.524 & 0.013 \\
\hline \multirow{6}{*}{$\begin{array}{l}\text { 2(DV): Public } \\
\text { Trust }\end{array}$} & Constant & $0.869 * * *$ & 0.294 & & 2.959 & 0.004 \\
\hline & Tangible & 0.017 & 0.090 & 0.018 & 0.192 & 0.848 \\
\hline & Reliability & $0.352 * * *$ & 0.085 & 0.412 & 4.115 & 0.000 \\
\hline & Responsiveness & $0.179 * *$ & 0.086 & 0.202 & 2.085 & 0.039 \\
\hline & Assurance & 0.132 & 0.091 & 0.140 & 1.457 & 0.148 \\
\hline & Empathy & 0.139 & 0.106 & 0.131 & 1.320 & 0.189 \\
\hline 3(DV): & Constant & $5.089 * * *$ & 0.841 & & 6.050 & 0.000 \\
\hline Public Trust & Public Satisfaction & $0.643^{* * * *}$ & 0.060 & 0.700 & 10.658 & 0.000 \\
\hline \multicolumn{7}{|c|}{ * $\quad$ Significant at alpha $10 \%$} \\
\hline *** Significan & $\begin{array}{l}\text { Ipha } 5 \% \\
\text { lpha } 1 \%\end{array}$ & & & & & \\
\hline
\end{tabular}

Regression of Model 1 rejected the hypothesis that service quality's tangible and responsive dimensions influenced public satisfaction of the COVID-19 services provided. Consumers or the public do not differentiate public satisfaction based on tangible values such as the orderly and cleanliness of public services delivery, clear treatment rooms, and public health workers' appearance. The public also did not value responsiveness of the public services measured by scheduled services, public health workers' availability when is needed, and availability of hotline numbers for getting COVID-19 services. These findings suggested that the tangible and responsiveness of COVID-19 services did not create additional value-added to public satisfaction.

For the $2^{\text {nd }}$ Model, only reliability and responsiveness variables positively influenced public trust. The reliability variable positively and significantly influences public trust in delivering COVID-19 services at a 99 percent confidence level. In contrast, the responsiveness variable was significant at a 95 percent confidence level. It was interesting to see the responsiveness directly influencing public trust, but it does not influence public satisfaction. The government responsiveness dimension of service quality measures the availability of service schedule, the will to help the public, and availability of hotline numbers. These public health services might not up to the public satisfaction, but they were essential to building public trust in government. This mixed finding suggested government responsiveness to demand COVID-19 services building public trust in the government event though customers felt unsatisfied with the services. Second model regression also gave a mixed result for the empathy variable. The ability to understand the public needs of COVID-19 services did not create public trust in the government. Instead, it contributed to public satisfaction with the COVID-19 services delivered to consumers.

Table 3 in the last row presents the regression results of Model 3. It was found that public satisfaction positively influenced public trust. The relation was strongest compared to other correlations in the study with a regression coefficient of 0.643 and significant at $99 \%$ confidence level. 


\section{CONCLUSION}

This study provides clear evidence of the positive influence of service qualities on public satisfaction and public trust. Under the COVID-19 pandemic situation where the public faces unprecedented lifethreatening disease, Jakarta citizens show the reliability of public health services that contributed to public satisfaction and public trust in government. It was essential for Jakarta's government to provide its citizens with sufficient information about COVID-19 and keep the privacy of COVID-19 patients. The study revealed the contribution of public service quality to public satisfaction and public trust. Even though the result showed that public service quality did not create public trust, one dimension of public service quality, namely assurance, could build public satisfaction. Public health service built public satisfaction by providing sufficient securities for people using the service, retaining good ethics of the health care workers, and showing good performance. The same finding was found in the empathy dimension of the service quality. Some factors in Jakarta's government performance, such as meeting public expectations on service delivery and catering to the consumers' needs, had given some contributions to public satisfaction. Jakarta's government responsiveness in dealing with the demand for COVID-19 services created public trust in the government. The government responsiveness dimension of service quality measured the availability of service agenda in the health care, the willingness to help the public, and the availability of providing hotline service. Contrary to Yusuf's study in 2017, this study showed a strong and positive relationship between public satisfaction and public trust.

This study only examined public health services delivered by the government of Jakarta. It is recommended to expand the study to public health services provided by other governments in Indonesia or even assess the national government's public health service. Getting more randomized samples for future studies will improve the quality of the sample.

\section{REFERENCES}

Adly, H. M., Aljahdali, I. A., Garout, M. A., Khafagy, A. A., Saati, A. A., \& Saleh, S. A. K. (2020). Correlation of COVID-19 pandemic with healthcare system response and prevention measures in Saudi Arabia. International Journal of Environmental Research and Public Health, 17(18), 1-13. https://doi.org/10.3390/ijerph17186666

Al-Damen, R. (2017). Health Care Service Quality and Its Impact on Patient Satisfaction "Case of AlBashir Hospital." International Journal of Business and Management, 12(9), 136-152. https://doi.org/10.5539/ijbm.v12n9p136

Azhar, M. (2020). Government Strategy in Implementing the Good Governance during COVID-19 Pandemic in Indonesia. Administrative Law and Governance Journal, 3(2), 300-313. https://doi.org/10.14710/alj.v3i2.300-313

Baskoro, R. R., Arvianto, A., \& Rinawati, D. I. (2016). Penilaian Kepuasan Pasien Dengan Menggunakan Metode Servqual Guna Meningkatkan Kualitas Pelayanan Di Rsud Ungaran. Penilaian Kepuasan Pasien Dengan Menggunakan Metode Servqual Guna Meningkatkan Kualitas Pelayanan Di RSUD Ungaran, Industrial Engineering Online Journal, 5(4).

Boshoff, C. \& Gray, B. (2004). The relationships between service quality, customer satisfaction and buying intentions in the private hospital industry. South African Journal of Business Management, 35(4), 27-38. https://doi.org/10.4102/sajbm.v35i4.666

Chang, C-S., Chen, S-Y., \& Lan, Y-T. (2013). Service quality, trust, and patient satisfaction in interpersonal-based medical service encounters. BMC Health Services Research, 13(1), 1-11. https://doi.org/10.1186/1472-6963-13-22

Christensen, T. \& Laegreid, P. (2005). Trust in Government: The Relative Importance of Service 
Satisfaction, Political Factors, and Demography. Public Performance \& Management Review, 28(4), 487-511. https://doi.org/10.1080/15309576.2005.11051848

Davenport, M. H., Meyer, S., Meah, V. L., Strynadka, M. C., \& Khurana, R. (2020). Moms Are Not OK: COVID-19 and Maternal Mental Health. Frontiers in Global Women's Health, 1(June), 1-6. https://doi.org/10.3389/fgwh.2020.00001

Di Virgilio, F. \& Antonelli, G. (2017). Consumer behavior, trust, and electronic word-of-mouth communication: Developing an online purchase intention model. Soc. Media Knowl. Manag. Appl. Mod. Organ., 1, 58-80, doi:10.4018/978-1-5225-2897-5.ch003

European Centre for Disease Prevention and Control (2020). Download historical data (to 14 December 2020) on the daily number of new reported COVID-19 cases and deaths worldwide. European Centre for Disease Prevention and Control, 2020 (December 2020), 2020-2022. https://www.ecdc.europa.eu/en/publications-data/download-todays-data-geographic-distributionCOVID-19-cases-worldwide

Firmansyah, M. I., Rahmanto, F., \& Setiawan, D. (2020). the Preparedness for the COVID-19 Pandemic Management in Indonesia. Jurnal Administrasi Kesehatan Indonesia, 8(2), 188-201. https://doi.org/10.20473/jaki.v8i2.2020

Garg, S., Basu, S., Rustagi, R., \& Borle, A. (2020). Primary Health Care Facility Preparedness for Outpatient Service Provision During the COVID-19 Pandemic in India: Cross-Sectional Study. JMIR Public Health and Surveillance, 6(2), e19927.

Gille, F., Smith, S. C., \& Mays, N. B. (2014). Why public trust in health care system matters and deserves greater research attention. Journal of Health Services Research \& Policy, 20(1), 62-64.

Gronroos, C. (1984). A Service Quality Model and its Marketing Implications. European Journal of Marketing, 18(4), 36-44. https://doi.org/10.1108/EUM0000000004784

Kampen, J. K., Maddens, B., \& Vermunt, J. K. (2003). Trust and satisfaction: A Case study of the MicroPerformance. In A. Salminen (Ed.), Governing Networks (pp.319-326). IOS Press.

Karunarathne, H. M. L. P., Gunawardhana, W. H. T., \& Edirisinghe, J. (2015). Analysis of Public Satisfaction on Services Quality of Urban Local Authorities in Sri Lanka. Proceedings of $12^{\text {th }}$ International Conference on Business Management, $7^{\text {th }}$ and $8^{\text {th }}$ December 2015, Colombo, Sri Lanka. https://doi.org/10.2139/ssrn.2699879

Kim, Y., Seo, E., Seo, Y., Dee, V., \& Hong, E. (2018). Effects of Middle East Respiratory Syndrome Coronavirus on post-traumatic stress disorder and burnout among registered nurses in South Korea. International Journal of Healthcare, 4(2), 27-33. https://doi.org/10.5430/ijh.v4n2p27

Kruk, M. E. \& Laugesen, M. J. (2012). Perceptions of the health system and public trust in government in low-and middle-income countries: Evidence from the world health surveys. Journal of Health Politics, Policy and Law, 37(3), 405-437. https://doi.org/10.1215/03616878-1573076

Massola, B. J. (2020). Why Indonesia is losing the COVID fight while neighbours crush the virus. Retrieved from https://www.smh.com.au/world/asia/why-indonesia-is-losing-the-COVID-fight-whileneighbours-crush-the-virus-20201204-p56kmg.html

Nicomedes, C. J. C. \& Avila, R. M. A. (2020). An analysis on the panic during COVID-19 pandemic through an online form. Journal of Affective Disorders, 276, 14-22.

Pandey, M. (2020). The Impact of Pandemic COVID -19 in Workplace. European Journal of Business and Management, June, 8-18. https://doi.org/10.7176/ejbm/12-15-02

Parasuraman, A., Zeithaml, V. A., \& Berry, L. L. (1988). SERVQUAL: A multiple-item scale for measuring consumer perceptions of service quality. Journal of Retailing, 64(1), 12-37.

Purwanto, H. (2017). Indonesia Ranks First in Public Trust in Government. Retrieved from https://en.antaranews.com/news/111919/indonesia-ranks-first-in-public-trust-in-government

Putri, R. S., Purwanto, A., Pramono, R., Asbari, M., Wijayanti, L. M., \& Hyun, C. C. (2020). Impact of the COVID-19 Pandemic on Online Home Learning : An Explorative Study of Primary Schools in Indonesia. 
International Journal of Advanced Science and Technology, 29(5), 4809-4818.

Rubogora, F. (2017). Service Quality and Customer Satisfaction in Selected Banks in Rwanda. Journal of Business \& Financial Affairs, 06(01), 1-11. https://doi.org/10.4172/2167-0234.1000246

Salehi, A., Janati, A., Nosratnejad, S., \& Heydari, L. (2018). Factors influencing the inpatients satisfaction in public hospitals: A systematic review. Bali Medical Journal, 7(1), 17-26. https://doi.org/10.15562/bmj.v7i1.533

Song, H-J., Ruan, W., \& Park, Y. (2019). Effects of Service Quality, Corporate Image, and Customer Trust on the Corporate Reputation of Airlines. Sustainability, 11(12), 3302. https://doi.org/10.3390/su11123302

Van de Walle, S. \& Bouckaert, G. (2003). Public service performance and trust in government: The problem of causality. International Journal of Public Administration, 26(8-9), 891-913. https://doi.org/10.1081/PAD-120019352

World Health Organization (2020). COVID-19 Weekly Epidemiological Update 22. In World Health Organization (Issue December). https://www.who.int/docs/default-source/coronaviruse/situationreports/weekly_epidemiological_update_22.pdf

Yusuf, Y. (2017). Effect of Public Services Quality on Satisfaction and Its Implication on Public Trust. IOSR Journal of Business and Management, 19(02), 14-20. 